Multidisciplinary Journal of School Education Vol. 09, 2020/1 No. 17

ISSN 2543-7585 e- ISSN 2543-8409

DOI: $10.35765 / \mathrm{mjse} .2020 .0917 .03$

Submitted: 02.03.2020

Accepted: 07.05.2020

\title{
Aeddan Shaw
}

https://orcid.org/0000-0001-8622-1821

Jesuit University Ignatianum in Krakow

Faculty of Education

Institute of Modern Languages

Language and Culture Studies Department

e-mail:aeddan@outlook.com

\section{"What is History is What is Illustrated": The Utilization and Function of Images in History Coursebooks in Poland and Britain'}

\begin{abstract}
In a society which is increasingly visual, and with the teaching of history and critical thinking being important in an age of post-truth and fake news, the words of the Swedish poet Linn Hansén seem particularly apt: "what is history is what is illustrated". The images found in history coursebooks help learners to imagine the past, providing a visual aid to support learning, but they can also be used to foster critical thinking by treating the images as historical sources in themselves.

This paper presents the results of a pilot study on the functions of images in Polish and British history coursebooks using a proprietary paradigm based on existing scholarship in English Language Teaching. It shows that
\end{abstract}

1 The article takes its title from a line from Linn Hansén's powerful, yet playful poem, Gå till historien [Turn to History], a work that inspired the author to reflect upon this issue. For the insights and inspiration gleaned from this poem, the author is eternally grateful. 
the pedagogical functions of images in history coursebooks vary greatly between the two educational contexts. In Britain, images are typically treated as historical sources in themselves, whilst in Poland they typically perform more of a decorative function. The paper closes with a number of recommendations for further research and publishers of history coursebooks.

Keywords: visual culture, Polish \& British educational contexts, history teaching, ELT, critical thinking

\section{Introduction}

Ever since the publication of John Comenius's Orbis Sensualium Pictus (A World of Things Obvious to the Senses, drawn in Pictures), the power of images to support and foster learning has been well-known. In more recent times, this has only been compounded by the "visual turn" in the humanities and the growing awareness of the importance of visual literacy.

However, whilst the pedagogical functions of images have been considered for the best part of four decades in English Language Teaching, it is an issue that has been relatively overlooked in other disciplines (Donaghy \& Xerri, 2017; Goldstein, 2016; Hill, 2003). In the teaching of history, aside from a pioneering study by King-Sears and her colleagues on images in American history coursebooks, the issue has received almost no attention at all (King-Sears et al., 2018). King-Sears et al. indicated that images deployed in coursebooks for eighth graders were usually chosen well, but often failed to engage learners in critical thinking. Given that they can be a crucial aid in fostering both an understanding of and a response to history, this represents a considerable oversight on the part of publishers and editors of history coursebooks.

This pilot paper presents a study conducted on Polish and British history coursebooks. Adopting the well-established research paradigms from English Language Teaching (ELT) and adapting them to the context of history textbooks, it explored the functions of their images in order to determine to what extent they may be considered pedagogical (i.e., supporting learning) and to what degree they merely serve a decorative 
purpose. Beginning with an overview of the research in the field of ELT, it first discusses why the pedagogical function of images is important and then outlines the author's own paradigm before applying it in practice. The paper ends with a number of conclusions and recommendations for authors and publishers of history textbooks.

\section{The importance, utilization, and function of images in ELT coursebooks}

We are undoubtedly living, as many scholars have indicated, in an increasingly visual age and culture (Duncum, 2001). The instructional value of images is far from new, however, having been used for educational purposes since at least the Middle Ages. As well as serving a decorative function, stained glass windows in Gothic churches were also used pedagogically by priests to explain and illustrate parables and biblical stories (Reynolds, 2013). Indeed, as Dussel notes, "medieval Christianity supported a tight relationship between texts and images, whether explicit—as in illuminated books_or implicit—as in monumental sculptures that referred to texts" (Dussel, 2013). Comenius, however, was perhaps the first educator to explicitly highlight the pedagogical importance of images in his Orbis Sensualium Pictus (A World of Things Obvious to the Senses, drawn in Pictures).

The first major, explicit study of the functions of images in ELT coursebooks was conducted by Hill in 2003. He divided them into two intuitive categories, decorative and useful, concluding that the majority of images (55\%) fell into the former (Hill, 2003). Romney, arguably the leading scholar in the field, conducted his first study in 2012. Drawing on a much older typology proposed by Levin in 1981, Romney formulated six functions for the images found in ELT coursebooks (Romney, 2012). Arguably because of the methodological assumptions he adopted, but also potentially because of the relatively limited corpus which he drew upon (only Japanese coursebooks), he found that only $18 \%$ should be considered as serving a solely decorative purpose. 
A more recent study by the same author presented another typology, this time featuring three categories and four roles (Romney, 2019). In this case, images could be categorized as decorative, instructional, or supportive. This was supplemented by the further distinction of the roles that they could play in a coursebook, namely, decorative, weakly supportive, strongly supportive, or instructional. In his study, he determined the vast majority of images (82.4\%) to be strongly supportive and instructional. He adopted the following workflow:

\section{Figure 1}

Image Categories and Roles

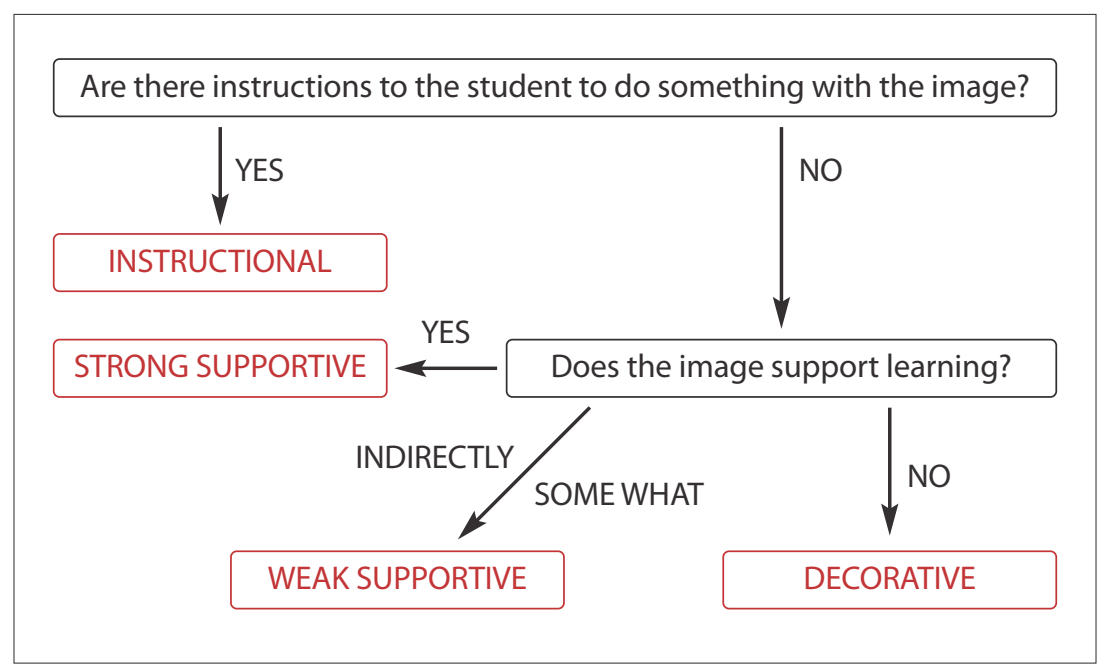

Note. (Romney, 2019)

It is unclear whether the disparity between the results of Hill in 2003 and Romney in 2019 represents the sea change that has occurred in the utilization of images in ELT coursebooks or that the different methodological assumptions of each study are responsible. Presumably, a repeat analysis of Hill's chosen coursebooks using Romney's methodology would be advantageous in this respect. However, that is not the purpose of this article, and the outline sketched above regarding ELT coursebooks was merely intended to show that the issue has received attention in the field. 
However, Romney's methodology requires some adaptation before it can be applied to history coursebooks. Firstly, it is necessary to determine whether the image is instructional or not, which is based on whether there are "instructions to the student to do something with the image". Whilst this is perfectly acceptable for an ELT model, given the vital role performed by images in communicative language teaching, those in history coursebooks play different semiotic and pedagogical functions. Another key drawback is the fuzziness of how to code the distinction between "strongly supportive" and "weakly supportive." Even an image with little supporting information could be exploited well to support learning in a classroom setting, and it is far from clear as to the difference between "strongly" and "weakly" supportive, since no criteria were given in the methodology.

Drawing on the insights and experiences of Hill, Romney, and KingSears et al., this study includes its own proprietary paradigm, one more suited to analyzing history coursebooks. It should be stressed that this is formed around the pedagogical functions of images (i.e., how they can be exploited for teaching and learning) and is not an attempt to determine the semiotic functions of the images.

\section{Methodology}

Whilst Romney's 2019 study has much in its favor, I decided to formulate a slightly different methodology for analyzing history coursebooks. My method borrows the names of its categories from Callow's three dimensions of viewing: affective, compositional, and critical (Callow, 2005). Despite being indebted to Callow for the use of his terms, the sense in which he uses them is more rooted in the theory of visual literacy and semiotics, rather than pedagogy. As a result, the following categories and descriptions were established:

Affective - The image serves a primarily decorative or illustrative function, intended to arouse an esthetic response, making the text and work as a whole more attractive, but not explicitly meant to be exploited 
when teaching, i.e., there is no explanatory text or context which is intended to support learning. For example, a modern illustration or picture of Henry VIII or Mieszko I, without any accompanying attribution, task, or explanation would be considered affective. Similarly, an unlabeled image representing a historical figure, even if it constitutes a historical source itself, would be considered affective if there is no information concerning the context of its composition or if none of its features are highlighted.

Compositional - The image is used to support learning or provide historical context, i.e., it illustrates or depicts something that accompanies a written explanation, or there is a broader context of the image's composition or features. For example, a painting of Henry VIII or Mieszko I by a contemporary of theirs - with a date of composition and/or other information-would be considered compositional. Similarly, an infographic of a castle, with different parts labelled and with explanatory text, would be classified as compositional. In contrast, an unlabeled, contemporary picture of a castle would be considered an affective image.

Critical - The image is accompanied by a task which requires the viewer to engage in critical thinking or analysis. For example, a painting of Henry VIII or Mieszko I by a contemporary, with a date of composition and/or other information, which requires the viewer to consider factors such as the manner of depiction or the artist's intention, or perhaps to make a comparison with the present day. Furthermore, any image which is accompanied by explicit instructions to reflect on it (whether in terms of its composition, context, or features) would lead to it being classified as critical.

The importance of critical images is based on Loewenstein's (2007) pioneering investigation into curiosity. He showed that heightened learner engagement and extended contributions are typically found wherever there is a gap of some kind between the participants which needs to be filled. Critical images, where students are asked to complete an information gap using the image and the information it contains, would thus be more stimulating and engaging for learners. Loewenstein identifies four main types of situations which may lead to the creation of an information gap: 
"1. The posing of a question or presentation of a riddle or puzzle"; ".... 2. Exposure to a sequence of events with an anticipated but unknown resolution";...." 3. The violation of expectations often triggers a search for an explanation";...."4. Possession of information by someone else also causes curiosity." (Loewenstein, 2007).

As other scholars have noted, the psychology of curiosity is a fascinating field and curiosity is likely to be engaged when a balance is struck between being too explicit or too vague (Kidd \& Hayden, 2015). Therefore, it is assumed that critical images are more conducive to engaging learners and more likely to result in the kind of critical thinking that history requires.

Evidently, such categories are far from clear cut, and since this was a pilot study, no Romneyan style division into weakly or strongly supportive was ventured. To ensure consistency, the analysis was conducted three times on all works, with an average taken if there was a discrepancy in the numbers between the different counts.

Thus, counts of images in four history coursebooks (two Polish and two British) were conducted and the images were classified according to the three functions. Illustrations in titles, timelines, cartoon "guides," or accompanying characters were omitted from the count. In addition, maps were not included since a full consideration of their functioning merits a study in itself The decision to analyze coursebooks from two different educational contexts was motivated by the desire to avoid some of the limitations of previous ELT studies (e.g., Romney's was limited to the Japanese context) and to allow some, albeit limited, comparisons to be made between the two.

Therefore, the research task that was envisaged for the study, as depicted in Figure 2, was to classify images in four history textbooks as affective, compositional, or critical, in order to determine whether there have been changes over time (between the two British coursebooks, published in 1991 and 2019) and whether there are differences between educational contexts (Poland and Britain). 
Figure 2

The research procedure used

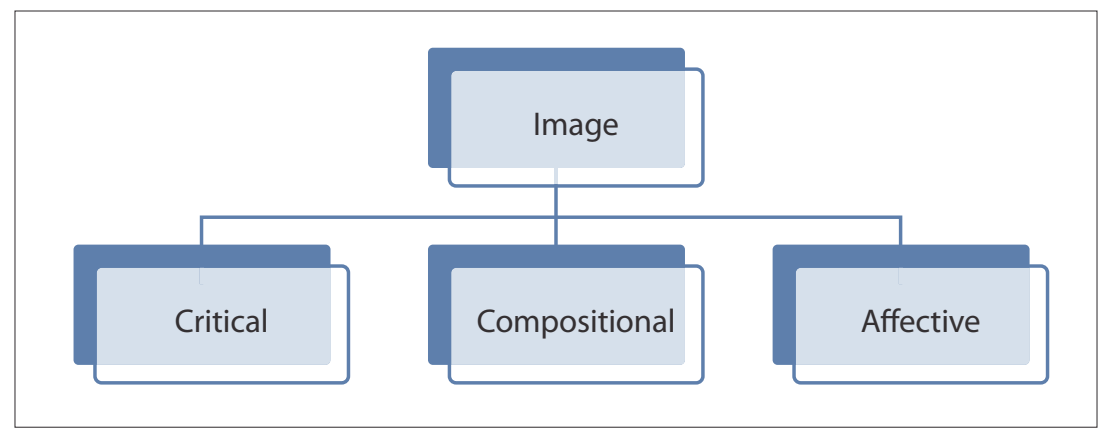

\section{Pilot study}

The following four coursebooks were chosen for the pilot study:

- Understanding History 1. Heinemann. (Child, Shuter, \& Taylor, 1991)

- KS3 History 4th Edition: Invasion, Plague, and Murder: Britain 1066-1558. OUP. (Wilkes, 2019)

- Wczoraj i Dziś 5. Nowa Era. (Wojciechowski, 2018)

- Historia 5. Gdańskie Wydawnictwo Oświatowe. (Małkowski, 2018)

Three of them represent the most recent publications in the field. One-Understanding History 1 - was first published 30 years ago and was selected for contrastive purposes. Despite differing in terms of the national focus, Understanding History 1, Wczoraj i Dziś 5, and Historia 5 cover the same time period.

Table 1 contains the results of the case study, showing both total numbers and percentages for the three functions of images: 


\section{Table 1}

Count of Images According to the Three Functions

\begin{tabular}{|l|c|c|c|c|c|}
\hline \multicolumn{1}{|c|}{ COURSEBO0K } & IMAGES (TOTAL) & $\begin{array}{c}\text { AVERAGE } \\
\text { (PER PAGE) }\end{array}$ & AFFECTIVE & COMPOSITIONAL & CRITICAL \\
\hline Understanding History 1 & 134 & 1.05 & $32(24 \%)$ & $15(11 \%)$ & $87(65 \%)$ \\
\hline $\begin{array}{l}\text { Invasion, Plague, and } \\
\text { Murder: Britain 1066-1558 }\end{array}$ & 155 & 0.71 & $78(50 \%)$ & $48(31 \%)$ & $29(19 \%)$ \\
\hline Wczoraj i Dziś5 & 218 & 0.99 & $164(75 \%)$ & $54(25 \%)$ & 0 \\
\hline Historia 5 & 221 & 1.05 & $179(81 \%)$ & $42(19 \%)$ & 0 \\
\hline
\end{tabular}

Some inferences can be made from the image analysis:

- There is a clear absence of critical images in Polish history books, despite the books being as visual or even more so than their British counterparts (i.e., they have the same number of images per page or more).

- Polish coursebooks use considerably more affective images than compositional ones.

- British coursebooks label and treat a significant percentage of images as "sources," where students are encouraged to interpret them as part of the historical record. The absence of such labels and treatment in Polish coursebooks contributes to them being used more for decorative or affective purposes.

- There has been a reduction in the number of critical images in British coursebooks, and a rise in the use of compositional images.

A particularly illuminating example of the way in which images are utilized across the coursebooksis the reproduction of the Capitoline Wolf, which is featured in Understanding History 1, Historia 5, and Wczoraj i Dziś 5. Despite using photographs of the same sculpture, the three books treat the image in very different ways. Wczoraj i Dziś 5 attaches to the image a textbox containing the following information: 
The Capitoline Wolf is a sculpture which is a symbol of Rome. It takes its name from the Capitoline, one of the hills that Rome spread over. It is in the museum located there that one can admire this famous sculpture. The work presents a wolf feeding the twins, Romulus and Remus, who would later become the founders of the city. (Wojciechowski, 2018, p. 77) ${ }^{2}$

Historia 5, the other Polish coursebook, has the same image, accompanied by the following text: "A sculpture from the 5 th century BCE showing the Capitoline Wolf (which is to be found in the museum on the Capitoline Hill in Rome). The figures of Romulus and Remus were only added in the 15th century" (Małkowski, 2018, p. 60). ${ }^{3}$ Both of these uses were classified as compositional, since they provided context and information directly related to the image. However, students are not explicitly instructed to do anything with this knowledge or image. In contrast, Understanding History 1 exploits the image in a very different way. As well as being accompanied by text-_A bronze statue of the she-wolf which looked after Romulus and Remus. It was made in the 6th century BCE" - the opposite page has the following task: "Study Source A [the image] and Source $C$. What do the sources tell us about the way Rome began?" (Child, Shuter, \& Taylor, 1991, pp. 20-21).

This is a task which requires pupils to critically reflect on the statue and its symbolic role; it is the kind of task which accompanies as many as $65 \%$ of the images in this coursebook. The Loewenstein information gap created by the combination of text and image, the author believes, would help to foster curiosity and engagement in a way that the Polish coursebooks do not, despite being clearly superior in terms of picture quality and presentation.

As an interesting aside, all three coursebooks contain incorrect information in relation to the image itself. Understanding History 1 presents the statue as having been cast in the 6th century BCE, whilst Historia 5 cites

2 Translated by the author.

3 Translated by the author. 
the more standard 5th century BCE ascription; Wczoraj i Dziś 5 makes no reference. However, research conducted over 12 years ago confirmed that the statue was cast during the early Middle Ages, at some point in the 13th century (Hooper, 2008). Whilst this is forgivable in the case of Understanding History (since it was published in 1991), Historia 5 was published 10 years after this fact became known. This is a considerable oversight on the part of the publishers and is particularly surprising given that both coursebooks passed through the extensive approval process conducted by the Ministry of Education in order to become official coursebooks.

\section{Limitations of the study}

Clearly, four coursebooks represents a relatively small sample, although the present study is intended as a pilot one to be developed over a larger corpus in the future. Three of the books cover exactly the same time period, but Invasion, Plague, and Murder: Britain 1066-1558 only covers the latter one-third encompassed by the others. This may have influenced the results, but the comparison between the other three texts remains valid.

\section{Conclusions and suggestions}

There are clearly identifiable ways in which images are presented and exploited between Polish and British history coursebooks. Perhaps the most important one is that Polish history coursebooks typically treat images as something separate from the main body of text and not as historical sources in their own right. As a result, the images rarely contribute to the creation of an information gap as envisaged by Loewenstein and thus are not as engaging or likely to foster critical thinking as their British counterparts.

Whilst the Polish coursebooks are typically attractively laid out, colorful, and visual, the way in which they utilize images could and should 
be altered in order to promote critical thinking. In subsequent editions, this could be done relatively simply by labelling the images as "sources" and by inserting an accompanying text box with a task to encourage students to use them in critically interpreting their content, context, and functions. In turn, this would undoubtedly help to make them a more engaging and useful resource for teaching the hypervisual learners of the 21 st century.

Potential avenues for future research include using the paradigm adopted here to analyze other coursebooks used for teaching history, for example at the tertiary level, and repeating the study with a different set of coursebooks covering a different period of history. The latter would ensure that the use of images in the two contexts is not rooted in the particularities of teaching the period and age group in question. 


\section{References}

Callow, J. (2005). Literacy and the visual: Broadening our vision. English Teaching: Practice and Critique, 4(1), 6-19.

Child, J., Shuter, P., \& Taylor, D. (1991). Understanding History. Retrieved from https://books.google.pl/books?id=Q2acYjrx3rEC

Donaghy, K., \& Xerri, D. (2017). The image in English language teaching. https://doi.org/10.1016/j.rser.2017.04.009

Duncum, P. (2001). Visual culture: Developments, definitions, and directions for art education. Studies in Art Education, 42(2), 101-112. https://doi.org/10.2307/1321027

Dussel, I. (2013). The visual turn in the history of education: Four comments for a historiographical discussion. In T. S. Popkewitz (Ed.), Rethinking the history of education: Transnational perspectives on its questions, methods, and knowledge (29-49). https://doi.org/10.1057/9781137000705_2

Goldstein, B. (2016). Visual literacy in English language teaching. Cambridge Papers in ELT Series.

Hill, D. A. (2003). The visual elements in EFL coursebooks. In B. Tomlinson (Ed.), Developing materials for language teaching (174-182). London: Continuum Press.

Hooper, J. (2008, July 10). Radio-carbon tests reveal true age of Rome's shewolf-and she's a relative youngster. The Guardian.

Kidd, C., Hayden, B. Y. (2015). The psychology and neuroscience of curiosity. Neuron, 88, 449-460. https://doi.org/10.1016/j.neuron.2015.09.010

King-Sears, M., Berkeley, S., Arditi, O., Daley, H., Hott, B., \& Larsen, A. (2018). Analysis of visual representations in middle school U.S. history texts. Journal of Visual Literacy, 37, 85-102. https://doi.org/10.1080/1051144X.2018.1486563

Małkowski, T. (2018). Historia 5. Podróże w czasie (1st ed.). Gdansk: Gdańskie Wydawnictwo Oświatowe.

Reynolds, E. A. (2013). The development of stained glass in Gothic cathedrals. JCCC Honors Journal, 4(1).

Romney, C. (2012). Images in ELT textbooks: Are they just decoration? In A. Stewart \& N. Sonda (Eds.), JALT2011 Conference Proceedings.

Romney, C. (2019). The purposes of images in ELT textbooks reexamined. The 2018 PanSIG Journal. 
Wilkes, A. (2019). KS3 history: Invasion, plague and murder - Britain 1066-1558 Student Book (4th ed.). Retrieved from https://books.google.pl/books?id=U_JlwgEACAAJ

Wojciechowski, G. (2018). Wczoraj i dziś 5. Podręcznik do historii dla szkoły podstawowej (1st ed.). Nowa Era. 
ISSN 2543-7585 e- ISSN 2543-8409

DOI: $10.35765 / m j s e .2020 .0917 .04$

Submitted: 12.12 .2019

Accepted: 08.05.2020

\title{
Jorge Martínez Lucena
}

https://orcid.org/0000-0001-9687-3057

Abat Oliba CEU University in Barcelona

Faculty of Communication, Education, and Humanities

Department of Education and Humanities

e-mail: jorge_profesor@icloud.com

\section{Cristina Rodríguez Luque}

https://orcid.org/0000-0002-3719-772X

San Pablo CEU University in Madrid

Faculty of Humanities and Communication Sciences

Department of Audiovisual Communication and Advertising

e-mail: cristina.rodriguezluque@ceu.es

\section{Rosa lannuzzi}

https://orcid.org/0000-0001-6498-5601

Abat Oliba CEU University in Barcelona

e-mail: rosa.iannuzzi@tin.it

\section{Italian Education's View of Cinema: From Suspicion to Media Education}

\begin{abstract}
From the outset, the Italian educational system has been interested in the message of films and cinema's power of persuasion. Prior to the advent of television, it viewed cinema with suspicion for the alleged damage it caused to the minds of young people. Later, it would view cinema as a means of fascist ideological propaganda. From the 1920s onwards, schools would use cinema as a teaching aid through "educational cinema." Since 1960, schools have aimed to teach formal analysis and film content. On the threshold of the new millennium, the revolution in school autonomy obliged every
\end{abstract}


educational institution to independently manage the financial resources allocated to them. This involved the arrival of external experts who were entrusted with media education: they were supported by an internal tutor while the school coordinated the professionals who specialized in cinema; meanwhile the subject teacher entered the Internet era with the innovation of the interactive whiteboard, assuming the role of multimedia author. Thus began the training of teachers within schools, who were registered on the national list of Visual Education Workers.

Keywords: Italian education, cinema, teaching, propaganda, cross-mediality, media education

\section{Introduction}

In Italy, recent regulations on cinema provide for training activities which—although they are not curricular or cross-cutting — are entrusted to specialized figures who manage projects in schools funded by public institutions. Today, cinema is included within Media Education and is central in the training of internal teaching staff. This has not always been the case.

\section{Aims and method}

This study examines the use of the cinema media channel in Italian schools, from fascism to the present day. Through theoretical analysis, the historical and socio-cultural context are analyzed and the cinema as an educational tool is examined. In addition, the evolution of the cinema and the way it is used in schools are investigated, as are the main legislative measures that have governed the use of cinema and media as an educational tool in Italian schools. 


\section{The suspicion towards cinema}

The Italian cinema industry was born with the 20th century; from 1904 on, following the first projections in café concerts or accompanying circus or variety shows, the number of cinemas multiplied in cities to such an extent that by 1908 there were already 500 of them.

In 1907, the first Italian productions and distributions were created (Manetti, 2012). The first attention of the state towards this sector came from the President of the Council, Giovanni Giolitti, who with his May 15, 1907 Circular invited the Prefects to monitor productions that were offensive to good morals or that focused on spectacular deeds and tricks that caused fear or horror. This measure specifically referred to images of surgical or pornographic activities aimed at an adult public in large cities. In this way, the government came up against the enthusiasm towards cinema (Alovisio, 2015, 2019; Sacerdoti, 1910). Between 1913 and 1918, censorship would become even harsher (Guadagnini, 1918).

With Law 785 of June 25, 1913, the liberal state government, whose parliamentary president was Giolitti, centralized state censorship and subjected the sector to hefty taxation with the payment of 10 cents for each meter of film projected. The protests in the sector focused in particular on the consequences of this financial intervention. The progressive lengthening of films, which had developed the cinema, could now lead to a crisis.

The enormous spread of cinema halls led the government to replace the tax on film length with a ticket tax. However, this fiscal measure was adopted to satisfy well-meaning people who simultaneously judged cinema as potentially immoral and praised the superiority of the theater at a time when the public clearly preferred the cinema over the theater. In the 1914-1915 fiscal year alone, the tax on tickets sold in cinemas brought in over 2.12 million lire, while theatre and other show tickets yielded less than 90,000 lire (Manetti, 2012).

In short, in liberal pre-Fascist Italy, the cinema was considered more a source of tax revenues and of a concern over its moral influence than an area of educational opportunities. 


\section{Propaganda cinema}

With the advent of fascism in 1922, the Italian film industry found itself in disastrous financial conditions due to the high costs of the actors, who had become stars, and for the heavy taxation. Consequently, it suffered from competition from Hollywood productions, which, thanks to a favorable tax regime and the expansion of the domestic market, recovered their production costs even before being exported, and were thus able to be sold abroad at very competitive prices. For this reason, 20,000 workers in various sectors of the film industry, many of whom were famous actors, now found themselves in a state of misery and desperation.

However, Mussolini was a journalist and a school teacher, which meant that he was professionally capable of understanding the enormous potential of cinema. Firstly, he took measures to increase educational production. During Italian Fascism, cinema first became a teaching medium, with the foundation in 1924 of L'Cinema Unione Educativa (LUCE) (Laura, 2000). Even today, the LUCE Institute holds an educational archive which includes the series Cineteca Scolastica (School Film Library) with 37 titles.

During the Fascist era, the function of cinema, in addition to being educational, was also propagandistic. Of the more than 700 films produced by the LUCE Institute, 100 consisted of direct or indirect propaganda. Many of these films were screened outside and inside schools on the day the Fascist regime called Fascist Saturday, during which various activities took place to celebrate the regime, from gymnastic trials to parades of uniformed boys (Lentini, 2018). However, except in rare cases, schools did not have projectors in those days.

Thanks to the work of the LUCE Institute, Italy obtained important worldwide recognition for using the cinema for educational purposes. In fact, in 1928, the League of Nations approved Italy's proposal (outstripping France with a specific self-financed project) to create its International Educational Cinematography Institute (IECI) and establish its headquarters in Rome (Manetti, 2012, p. 58). Royal Decree 2025 of September 6, 
1928 allocated a substantial annual budget to the IECI to cover all its costs, which were entirely borne by Italy. The IECI had a representative office in Frascati, in the province of Rome, where it hosted meetings and conferences. Furthermore, the IECI was responsible for creating the International Review of Educational Cinematography, which was published in Italian and translated into French, English, German, and Spanish.

However, the regime saw an opportunity to use cinema to endorse the cultural policy of fascism abroad in an "attempt by Mussolini to build an image of the Regime for external use that was capable of succeeding in the Anglo-Saxon world, but without falling outside the achievements of the socialist world" (Manetti, 2012, p. 59). Indeed, the regime looked upon the Soviet cinema model with extreme interest. Unlike the Hollywood model, the state wholly managed the economic aspect and the quality of the content. However, the Italian film industry and the Fascist regime had a common enemy in the commercial cinema of Hollywood, which both asphyxiated Italian production and transmitted a model of capitalist life that was unpopular with the regime (Frescani, 2012).

Another important initiative in favor of cinema was the creation of the Experimental Film Center in 1935, which was a true university of cinema based in Rome. One of the Center's initiatives was the creation of Bianco e Nero (Black and White), the first important film journal and one that is still published today. It no longer conveyed to the public the image of films as mere products of leisure, but of art. Moreover, between 1927 and 1942, 46 decrees were issued for the benefit of the film industry (Cardillo 1987; Venturini, 2012).

Undoubtedly, a gloomy image began to emerge from 1933 onwards, the year that witnessed the advent of Nazism in Germany and in which Goebbels, Hitler's propaganda minister, visited Rome and showed Mussolini the operation of the new Nazi Propaganda Ministry, which he headed. The already consolidated fascist attention to the potential of film found new inspiration through Goebbels's visit. Like the Nazi Ministry, Royal Decree 1434 of September 6, 1934 gave rise to the State Undersecretariat for Press and Propaganda in Italy; initially, it had three Directorates-General: Italian Press, Foreign Press, and Propaganda, to which, with Royal Decree 
1565 of September 18, 1934, a fourth was added-Cinema-headed by Luigi Freddi, who in his inaugural speech celebrated the rebirth of Italian cinema, stating "the state frames, the state helps, the state rewards, the state controls, the state encourages" (Manetti, 2012, p. 81). Propaganda and culture merged under the same perspective. Not surprisingly, during a debate in the Chamber of Deputies for the approval of the budget for the sector for the period July 1937 to May 30, 1938, the deputy Carlo Maria Maggi defined cinema as "the most powerful weapon" of ethical and political propaganda (Parliamentary Acts of the Chamber of Deputies, session Thursday, May 13, 1937, p. 3734).

Shortly thereafter, Giuseppe Bottai, on a partial collision course with the regime, in his role as Minister of National Education, founded with Royal Decree 1780 the Autonomous Film Library for School Cinematography, with the aim of equipping schools with projectors and specially produced or purchased films. The demolition of a school in Rome in 2002 recovered the entire heritage of the Film Library, which consisted of 12,000 copies of educational short films, 20,000 films, 15,000 volumes, slides, extensive correspondence on the administrative events of the School Film Library, 500 AGFA projectors, and other machinery for the projection and making of films which had been made available to schools during the final years of Fascism and which had been lost. All the rediscovered material is now kept in the Lucana Film Library, in Oppido Lucano, a small town in southern Italy (Durante, 2011; Pietrafesa, 2012).

\section{The post-World War II period and educational cinema}

In the mid-1940s, the educational system began to take an interest in cinema, and it did so without questioning the distinction between educational and commercial cinema. A number of articles by Luigi Volpicelli published between July 1948 and the end of 1949 in Bianco e Nero (Volpicelli, 1948 a; Volpicelli, 1948 b; Volpicelli, 1949 a; Volpicelli, 1949 b; Volpicelli, 1949 c) marked the beginning of the reflection on cinema and education in Italy, still basing it on the preconception that 
everything which activates the imagination, the senses, and emotions did not have intellectual value and led young people towards uncritical acceptance of false values (Felini, 2015; Pierotti, 2013; Piromallo, \& Gambardella, 1998).

At the end of the 1940s and the beginning of the 1950s, Italian educators were somewhat wary about the use of film in educational work. They feared its hypnotic effect, also on the basis of their experience during fascism, which had promoted films with an explicit propagandist aim. Furthermore, the vast majority of educators believed that the study of the influence of spectacular cinema on young people was the responsibility of developmental psychologists and neuropsychiatrists (Rizzo, 2014).

In this context, the researcher Evelina Tarroni, investigating the use of cinemas by young people and their tastes in their choice of shows (Tarroni and Paderni, 1952), noted that "the perception of the film is greatly influenced by the personal experiences of individual spectators, and ... these experiences to a large extent arouse the interest of the viewer in the film" (Tarroni, 1950, p. 28) and consequently expressed perplexity towards the prevailing conception of the effects of film. Later, Laporta (1957) would attribute the vulnerability of young people to cinema to be not a behavioral psychological passivity, but a defect of mature intelligence.

In classrooms, the narrow-mindedness towards spectacular cinema went hand-in-hand with the use of so-called educational cinema, which instead fell under the field of pedagogy as a tool in the hands of the teacher. The teaching of the positivist era used the "cine-aid" to replace direct experience with the representation of phenomena that were dificult to observe in person (Farnè, 2006). While commercial cinema was suspected of every harmful effect, the educational cinema validated by schools was trusted in the mistaken illusion that it represented a transparent means of communication offering up reality as it is. In this way, educational cinema - considered an honest reproducer of objective reality and not subjected to any esthetic value analysis - in fact ended up being more insidious in classrooms than commercial cinema (Farnè, 2002). 
The regulatory level of cinema education was in accordance with fascism. The Lamberti Law of May 11, 1950 granted "provisions in favor of popular and educational cinematography". Subsequently, the Segni Law of March 24, 1953 repealed the law that in 1938 had established the Autonomous Film Library for School Cinematography ${ }^{1}$ and in turn established the National Center for School Audiovisual Subsidies and, at the local level, the Provincial Centers for School Cinematography under the authority of the Local Education Authorities. The new provisions continued to consider cinema meant for students to be an illustration, a textbook for moving images and sounds-rather than an artistic and narrative product with its own expression (Rizzo, 2014). An ideological gap was created between teachers and film critics. Teachers pointed out the differences between cinema and cine-aids-or rather, between commercial cinema and "educator" cinema-and identified them primarily in the setting, which was not a movie theater, but a classroom-or in other words, an environment set for a lesson accompanied by the aid of images, sometimes even without sound. Film critics, however, highlighted the devaluation of cinema in school practice. For the critics, educational cinema, in the absence of plot and dramatization, represented the opposite of cinema (Volpicelli, 1949).

\section{Film education in the television era}

From 1954 on, television began to arrive in Italian homes and the order envisaged by the educational system in cinema-aided teaching was disrupted. The new media context imposed a mass consumerist and extravagant culture of entertainment shows and "the sum of these minimal messages that accompany our daily life constitutes the most visible cultural phenomenon of the civilization in which we are called to operate" (Eco, 1964, p. 24). However, schools continued to show reality according

1 It was also known as the Bottai Film Library, after the Minister of National Education. 
to its traditional curriculum and its linear analytical procedure, although the same linearity was lost in the mass of information and news (Tarroni and Baldelli, 1970). After 1965, cinema underwent a technological transformation with Kodak's distribution of the Super 8 camera. At the same time, thousands of film clubs were created throughout Italy. The most attentive pupils perceived what teachers experience in everyday life. In other words, through daily practice with television screens, students were helped to understand cinema (Baldelli, 1970), thereby invalidating years of research carried out in the pre-television era (Tarroni, 1960).

The educational world no longer looked upon cinema as a hypnotic plague from which to defend itself, but instead identified television as the new enemy. Consequently, while educational cinema gathered dust in the display cases of school buildings, commercial cinema emerged from the purgatory of prejudice to develop its new role as an educational tool (Rizzo, 2014). Academics of the era noted the paradoxical parallels between the old attitude of censorship and the new one. Baldelli (1970) reported that in the debate on the social impact of television "the same people who in the past attacked cinema now use the old arguments against the new means of mass communication" (Baldelli, 1970, p. 123). In the world of education, it became a general conviction that cinema, unlike television, "could favor a perceptual restructuring of everyday reality, dismembering the conceptual schematizations through which it is trivialized and repetitive" (Lumbelli, 1974, p. 21) and it was an established fact by that point that "it is no longer film that is pedagogical or didactic, but rather the communicative process into which it is incorporated to structure itself as such" (Farnè, 2006, p. 243). Therefore, schools abandoned educational cinema and asked themselves what could be done to teach cinema.

\section{The semiotic teacher}

The debate on the teaching of cinema in the late 1940s and early 1950s, which centered on the emotional dimension of film images and on 
the problem of understanding the narrative and linguistic structures of film in relation to the degree of intellectual development of young viewers, was not widely followed.

In the following decades, in fact, the teaching of cinema would become a little practiced field, almost exclusively the object of a manual production divided between content and linguistic approaches and equally limited in terms of methodological openness and theoretical proposals. (Pierotti, 2013, p. 78)

Between the 1960s and 1980s, the Italian educational system adopted a semiotic perspective and considered cinema not only the bearer of values, as it had done since the birth of cinema, but also in its formal aspect. The narrative theoretical foundations and the language of cinema became the object of teaching. Film education interpreted filmmaking as a study and examined all the signifiers of cinematographic language, such as framing and perspective. Cinema was dissected and classified and the general rules adopted by the professionals working in the field were elucidated.In a sense, it was considered painting in movement and, as in painting, its formal rules were explained first, followed by the values it transmits (Malavasi, Polenghi, \& Rivoltella, 2005; Rivoltella, 2017).

To demonstrate the persuasive capacity of the medium, teachers revealed the tricks behind the magic of cinema. Teachers chose to teach cinema from a narratological perspective in a voluntary, non-institutionalized way. From this perspective, teachers considered narrative cinema and included it in the teaching of Italian. Teaching interventions in schools focused on the functioning of cinema or the relationship between cinema and literature (Bernardi, 1991; Carluccio, 1988; Costa, 1993; Cremonini, 1988). The interest in the adaptation and transfer from the literary text to the cinematographic text was prevalent and sometimes functional when cinema was used as an ancillary aid in the teaching of school subjects, in this case of Italian and foreign literature (Cortellazzo \& Tomasi, 2008; Dusi, 2003).

The Ministry's policy documents relating to secondary, primary, and nursery schools-issued in 1979, 1985, and 1991—revealed that attention was paid to the media at the institutional level. Italian secondaryschool education appeared static compared to the other levels of the 
school system. The legacy of Giovanni Gentile's approach ${ }^{2}$ weighed upon it directly, at least until the 1950s, when "the decline of idealism brought scientific research to the fore once again and the use of methods inspired by it, reintegrating Italy into international teaching circles" (Laporta, 2001, p. 91), while the indirect conditioning derived from the spiritualist approach of idealistic teaching ${ }^{3}$ from 1985 onwards was overcome with the introduction of Computer Science as a subject. Overall, the regulatory framework highlighted the lack of a unitary coherent educational design for the various educational levels it addressed. The media appeared to be treated with a different approach: as languages of relevance, as an aspect of the child's cultural environment, or as a space for teaching innovation. Indeed, in Italy, when the technological model prevailed, the interest in teaching older, non-digital media was supplanted by the interest in new technologies; computers and the Internet were preferred to printed paper, photography, film, and television (Rivoltella, 2017).

As mentioned above, Italian schools focused on the message transmitted by film and on the language of cinema, but did so spontaneously - in other words, without a clear legislative strategy from the government. At the turn of the century, however, the school system established rules for the training and practice of teachers who were to educate students on the subject of cinema. The practices that fell under the voluntary initiative of certain film teachers were now institutionalized and planned at the national level. Schools clarified, even formally, what the method of cinema education should be. In 1999, the Ministry of Education, University, and Research (MIUR) intervened on training and funded the National Plan for the Promotion of the Teaching of Film and Audiovisual

2 Giovanni Gentile (1875-1944), philosopher, educationalist, politician, exponent of Italian idealism, and author of the 1923 reform of public education known as the Gentile Reform.

3 Idealist teaching believes in the self-education of the Universal Spirit present in everyone. Consequently, it does not consider any scientific notion or technique to be necessary in the communication between the teacher and the pupil. Moreover, it considers science to be a second-order activity with respect to philosophy and subjects that celebrate the spiritual: history, art, and literature. 
Language in Schools. The plan included an integrated training program during school service, and research and educational experimentation for teachers in all subject areas of each school level (Costantino, 2005). In the 2000-01 and 2001-02 school years, it involved 10,000 students, 1,000 teachers, and 500 schools throughout the country. However, it ended abruptly, without the planned third year being implemented. Nevertheless, the qualitative level of this experimentation was unparalleled by any other experience during the 20th century (Costantino, 2005).

\section{School autonomy and external experts}

Over the last twenty years, thanks to the growing development of information and communication technologies, the media landscape has been enriched with new media (Manovich, 2001), whose presence has become pervasive in the lives of children, used as symbolic resources to give meaning to their relational experiences and to organize their daily lives (Buckingham, 2003; Buckingham \& Sefton-Green, 1994). A cultural context emerged that supported an extended participation in the production and distribution of the media, which are processes now favored by facilitating technology and cost-cutting (Jenkins, 2006). Cross-mediality, or rather the possibility of operating simultaneously in and with different languages via the Internet, has profoundly changed the media scenario.

In teaching, cinema, in addition to being an archive with its pre-existing narratives that became established over its century of existence, was approached by reworking the archival works themselves. Indeed, cinema no longer offered non-manipulable training tools, but digital visions (Arcagni, 2016), in which everything the director imposed, from the narrative pacing to the editing, tended to disappear by virtue of a new domain offered to the viewer. Each film could be included in the narrative created by the viewer, which was different from the one offered by the director. In the school world, both pupils and teachers could be producers and consumers of cinema; the film-deconstructed and reduced to pieces-becomes a semi-finished product in classrooms from which to 
obtain material for an alternative editing. The "app generation" (Gardner and Davis, 2014), which uses only the Internet instead of watching TV, reading newspapers, or going to the cinema, appears to be very much at ease in the game of fragmentation and decontextualization typical of the "post-cinema" era (Arcagni, 2016).

Since the 1990s, schools have adopted Masterman's lessons (1985) and have based media education around the key concept of media as a representation. As a result, they stopped approaching cinema separately and turned their attention to all media and the entire media landscape. Media education had arrived in classrooms, a discipline bordering on the sciences of education and communication and whose objective was the study, teaching, and learning of modern means of communication from the ethical point of view of both democratizing knowledge and promoting active citizenship (Rivoltella, 2001, 2017).

Media education spread throughout Italy at a time when the reflection and experiences already established in schools were merged with the field of study that it recognized ${ }^{4}$ (Giannelli, 2006; Rivoltella, 2017). Consequently, in this sector in Italy, the theoretical epistemological research followed practical research which-in contrast-preceded the birth of media education itself. An example of anticipation, although carried out with teaching presuppositions and aims that were not always explicit, was the first experiences of film education through the cineforum and the experiments in filmmaking carried out with the Super 8 camera (Felini, 2015; Rivoltella, 2017).

The transition from centralization to autonomy of Italian schools ${ }^{5}$ enlivened the educational context and introduced dynamism and competition between schools. Educational institutions that became

4 The association, represented primarily by the Italian Association for Media and Communication Education (MED), founded in 1996, has played an important role in the spread of media education throughout Italy.

5 The transition of schools to independence is enshrined in Law 59/1997. However, the implementing regulation would arrive with Presidential Decree no. 275 of March 8, 1999, and only in 2001 would the new text in Paragraph 3 of Article 117 of the Constitutional Charter preserve the independence of schools. 
independent-not only in terms of education, but also in terms of management-received help in securing funding for their operations, especially by drawing on European structural funds $(P O N)$. Once the proposed projects concerning the teaching of cinema were approved, institutes were able to fund directors, actors, and other qualified professionals working in schools.

\section{The interactive multimedia whiteboard and the role of the teacher}

In 2006, the interactive whiteboard arrived in classrooms and the cinema became an environment in which to look for shared meanings (Rodríguez, 2016). Teachers had the opportunity to become multimedia creators, even in an impromptu way, during lessons. The interactive whiteboard-which in a single object encapsulates all the main educational technologies previously in use (video projector, video recorder, computer, and television)_introduces the potential of different multimedia languages and the interactivity of new media into classrooms, allowing students to participate in the construction of the lesson. Moreover, it favors the use of iconic resources in the daily teaching work with the students.

\section{The Visual Education Worker}

The need became urgent for new literacy in order to offer students tools to decode visual messages in a context where images predominate in the transmission of information. Consequently, government policies promoted image education programs and cinema was also strategically and stably incorporated into the world of education. All of this constitutes an important historical passage for the history of Italian cultural and cinematographic policies. In the last five years, processes that had been paused for many years were restarted, as demonstrated by the experience 
of the National Plan for the Promotion of the Teaching of Film and Audiovisual Language.

Since 2015, new laws have fostered institutionalized spaces for the inclusion of artistic languages in schools, including cinema. Law 107/2015, Article 1, Para. $7 \mathrm{c}$ sets out the principle of "strengthening skills in musical practice and culture, in art and art history, in cinema, and in techniques and media for the production and dissemination of images and sounds" (emphasis added). As a consequence of the provisions of Law 107/2015, image education became one of the objectives of Law 220/2016, the Film and Audiovisual Act. ${ }^{6}$ By enacting this law, legislators provided for requests for proposals to be issued by schools of all levels, as well as entities, foundations, and associations, in order to support and promote the study and use of cinema and audiovisual language in schools. Law 220/2016 established an annual fund for the sector and established the Superior Cinema and Audiovisual Council, which was based on the structure of the General Directorate of Cinema of the Ministry of Cultural Heritage and Activities and Tourism (MIBAC).

In the application of Law 220/2016, the MIBAC and the MIUR, based on the Memorandum of Understanding of March 2, 2018, jointly promote the National Film Plan for Schools to include film and audiovisual language in schools as an educational cross-curricular tool. In reality, the Plan does not concern cinema explicitly, but more generally addresses the culture of audiovisual media that cinema introduced and continues to lead from a privileged position. It offers applicants funds for school initiatives dedicated to the moving image through selection and funding procedures (MIUR, 2018). For the 2017-18 and 2018-19 school years, the Plan has already provided resources amounting to 23.5 million euros through the issuing of five requests for proposals from entities, foundations, associations, and schools of all levels. The calls attracted a large

6 Article 27, Section i provides for the support, in agreement with the Ministry of Education, University, and Research, for the strengthening of skills in cinema and techniques and media for the production and dissemination of images and sound, as well as literacy in art and techniques and media for the prodcution of images and sound, pursuant to Article 1, Para. 7, Sections c and f of Law 107 of July 13, 2015. 
participation, with over 800 projects submitted and 496 projects funded. Participation in the regional tenders were proportional to the school populations, led by Lazio (167 projects), Campania (100), and Lombardy (97). The selected initiatives concerned and involved all types of schools, including comprehensive schools, which represent $36.6 \%$ of the participating educational institutions. However, for the 2019-20 school year, resources amounting to 12 million euros were made available (MIUR, 2019). Teacher training will guarantee nationwide coverage and will be managed, through a single training model, by schools awarded the tender for Visual Education Workers in School. This is new for the Italian educational context, which has followed more than one directive with respect to cinema as an educational tool over the years.

\section{Conclusions}

The aim of this work was to provide a historical reconstruction of the Italian context in which the school film culture was born and developed. The analysis was based on the legislation that has governed the use of cinema as a teaching tool over time.

The historical analysis has highlighted the influence of the political climate, in which the transition from fascist dictatorship to democracy influenced the vision of film, from propaganda to educational purposes.

On the meaning of film education, the various visions that schools have adopted are illustrated, from those of the 1950s that focused on educational cinema and excluded commercial cinema from the classrooms, to the arrival in Italy of media education.

Schools and teaching have evolved and cinema has changed. Crossmediality has entered classrooms, which has created the perspectives of media education. It is hoped that Italian schools will no longer need to rely on external workers and will be able to adapt itself and its teaching staff to the new scenarios. 


\section{References}

Alovisio, S. (2015). Cinematografo o proiezioni luminose? Immagini fisse e animate nel primo dibattito italiano sulle proiezioni educative. Immagine, 11, 61-103. Alovisio, S. (2019). L'occhio sensibile: Cinema e scienze della mente nell'Italia del primo Novecento. Turin: Edizioni Kaplan.

Atti parlamentari della Camera dei Deputati, Tornata di giovedì 13 maggio 1937. Arcagni, S. (2016). Visioni digitali. Video, Web e nuove tecnologie. Turin: Einaudi. Baldelli, P. (1970). Il cinema e I'adolescente. In P. Baldelli \& F. Tarroni (Eds.), Educazione e cinema. Turin: Loescher.

Buckingham, D. (2003), Media education: Literacy, learning, and contemporary culture. Cambridge: Polity Press.

Buckingham, D., \& Sefton-Green, J. (1994). Cultural studies goes to school: Reading and teaching popular media. Taylor \& Francis.

Bernardi, S. (1991). Fare scuola con i film. Guida ragionata a 130 film in videocassetta divisi per materia. Florence: Sansoni.

Cardillo, M. (1987). Tra le quinte del cinematografo: Cinema, cultura e società in Italia 1900-1937 (Vol. 22). Bari: Dedalo.

Carluccio, G. (1988). Lo spazio e il tempo. Cinema e racconto. Turin: Loescher.

Cortellazzo, S., \& Tomasi, D. (2008). Letteratura e cinema. Bari: Laterza.

Costa, A. (1993). Immagine di un'immagine. Cinema e letteratura. Turin: UTET.

Costantino, M. (2005). Educare al film. Il piano nazionale per la promozione della didattica del linguaggio cinematografico e audiovisivo nella scuola. Milan: Franco Angeli.

Cremonini, G. (1988). L'autore, il narratore, lo spettatore. Cinema e racconto. Turin: Loescher.

Durante, M. (2011). Gli archivi della Cineteca Lucana. Economia della Cultura, 21(3), $331-340$.

Dusi, N. (2003). Il cinema come traduzione. Da un medium all'altro: letteratura, cinema, pittura. Turin: UTET.

Eco, U. (1964). Apocalittici e Integrati. Milan: Bompiani.

Farnè, R. (2002). Il cinema educatore. Studium Educationis, 3.

Farnè, R. (2006). Diletto e giovamento. Le immagini dell'educazione. Turin: UTET.

Felini, D. (Ed.). (2015). Educare al cinema: le origini. Riflessioni ed esperienze di pedagogia dei media fino agli anni della contestazione. Milan: Guerini. 
Frescani, E. (2012). Sperimentazione o documento? II dibattito sul film documentario in Italia negli anni Trenta. In P. Cavallo, L. Goglia, \& P. laccio (Eds.), Cinema a passo romano. Trent'anni di fascismo sullo schermo (1934-1963), 213-250. Naples: Liguori.

Gardner, H., \& Davis, K. (2014). Generazione App: La testa dei giovani e il nuovo mondo digitale. Milan: Feltrinelli.

Giannelli, R. (2006). MED: viaggio nella Media Education in Italia. Orientamenti pedagogici, 2006(1), 219-230. Retrieved May 7, 2020 from www.medmediaeducation.it/download/masterman-e-il-ruolo-che-ha-avutoper-la-me

Guadagnini, G. (1918). La censura degli spettacoli cinematografici. Rome: Tipografia delle Mantellate.

Jenkins, H. (2006). Convergence culture: Where old and new media collide. New York: University Press.

Jenkins, H. (2009). Confronting the challenges of participatory culture: Media education for the 21st century. Cambridge: MIT Press.

Laporta, R. (1957). Cinema e età evolutiva. Florence: La Nuova Italia.

Laporta, R. (2001). Avviamento alla pedagogia. Rome: Carocci.

Laura, E. G. (2000). Le stagioni dell'aquila: storia dell'Istituto Luce (Vol. 34). Rome: Ente dello spettacolo.

Lentini, S. (2018). II "sabato fascista" un modello pedagogico dogmatico e omologante. Quaderni di Intercultura, X, 227-236.

Lumbelli, L. (1974). La comunicazione filmica. Florence: La Nuova Italia.

Malavasi, P., Polenghi, S., \& Rivoltella, P. C. (Eds.). (2005). Cinema, pratiche formative, educazione. Milan: Vita e Pensiero.

Manetti, D. (2012). Un'arma poderosissima. Industria cinematografica e Stato durante il fascismo. 1922-1943. Milan: Franco Angeli.

Manovich, L. (2001). The language of new media. Cambridge: MIT Press.

Masterman, L. (1985). Teaching the media. London: Comedia.

Ministero dell'Istruzione, dell'Università e della Ricerca (MIUR). (2018). Piano Nazionale Cinema per la Scuola. Retrieved October 5, 2020 from http://www.miur.gov.it/web/guest/protocolli-d-intesa///asset_publisher/P2P3r27/BRWj/content/protocollo-di-intesa-miur-mibact-cine-1 
Ministero dell'Istruzione, dell'Università e della Ricerca (MIUR). (2019). Piano Nazionale Cinema per la Scuola, lanciati i nuovi bandi per I'anno scolastico 2019/2020. Retrieved October 5, 2020 from http://www.miur.gov.it/web/guest/-/piano-nazionale-cinema-per-la-scuolalanciati-i-nuovi-bandi-per-l-anno-scolastico-2019-2020

Pierotti, F. (2013). Film didattico e pedagogia del cinema in Italia nel secondo dopoguerra. Quaderni d'italianistica, XXXIV(2), 65-83.

Pietrafesa, M. (Ed.). (2012). Guida agli archivi della Cineteca Lucana. Censimento degli archivi privati conservati dall'Associazione Cineteca Lucana di Oppido Lucano. Ministero per i beni e le attività culturali. Soprintendenza Archivistica per la Basilicata.

Piromallo Gambardella, A. (Ed). (1999). Costruzione e appropriazione del sapere nei nuovi scenari tecnologici. Naples: Cuen.

Rivoltella, P. C. (2001). Media Education. Modelli, esperienze, profilo disciplinare. Rome: Carocci.

Rivoltella, P. C. (Ed.). (2002). I ragazzi del web. I preadolescenti e Internet: una ricerca. Milan: Vita e Pensiero.

Rivoltella, P. C. (2017). Media Education. Idea, metodo, ricerca. Brescia: La Scuola.

Rivoltella, P. C., \& Marazzi, C. (2001). Le professioni della media education. Rome: Carocci.

Rodríguez, C. (2016). La comunidad de aprendizaje en el entorno digital. In L. N. Ladeveze \& T. T. Lacave (Eds.), Autoridad familiar y competencia digital: investigación sobre la autoridad doméstica en la sociedad digital, 87-110. Madrid: Universitas.

Rizzo, G. (2014). Le forme del cinema per l'educazione. Il panorama italiano dagli anni '50 ad oggi. Milan: Franco Angeli.

Sacerdoti, F. (1910). Cinematofobia. Un fatto nuovo di una questione vecchia. Mostra Internazionale del Nuovo Cinema, Tra un film e l'altro. Materiali sul cinema muto italiano. 1907-1920, 97-98, Venice: Marsilio.

Tarroni, E. (1950). Filmologia Pedagogica. Milan: Viola.

Tarroni, E. (1960). Ragazzi, radio e Televisione. Bologna: Malipiero.

Tarroni, E., \& Baldelli, P. (Eds.). (1970). Educazione e cinema. Turin: Loescher.

Tarroni, E., \& Paderni, S. (1952). Cinema e gioventù. Studio degli aspetti sociali e dei motivi d'interesse, Rome: Edizioni dell'Istituto. 
Venturini, A. (2012). La politica cinematografica del regime fascista dal 1934 al 1938. In P. Cavallo, L. Goglia \& P. Iaccio (Eds.), Cinema a passo romano. Trent'anni di fascismo sullo schermo (1934-1963),159-195. Naples: Liguori.

Volpicelli, L. (1948a). Valore sociale del cinema. Bianco e Nero. Mensile di studi cinematografici e dello spettacolo, 1948(5), 26-32.

Volpicelli, L. (1948b). Tipi e attori. Bianco e Nero. Mensile di studi cinematografici e dello spettacolo, 1948, 23-27.

Volpicelli, L. (1949a). Il vero problema del cinematografo rispetto all'educazione. Bianco e Nero. Mensile di studi cinematografici e dello spettacolo,1949(5), 3-8.

Volpicelli, L. (1949b). Pregiudiziali sull cinema e l'educazione. Bianco e Nero. Mensile di studi cinematografici e dello spettacolo, 1949(9), 51-60.

Volpicelli, L. (1949c). Cinema didattico e pedagogia. Bianco e Nero. Mensile di studi cinematografici e dello spettacolo, 12, 34-39. 